\title{
Market Analysis of Extruded Field Bean Flour Food Product Potential
}

\author{
Samanta Gaile1, Iveta Dembovska², Inese Silicka3 ${ }^{3}$, \\ Erika Teirumnieka ${ }^{4}$ \\ ${ }^{1}$ Mg.sc.ing., lecturer, Rezekne Academy of Technologies, Rezekne, Latvia, \\ e-mail: Samanta.Gaile@rta.lv \\ ${ }^{2}$ Mg.oec., researcher, Rezekne Academy of Technologies, Rezekne, Latvia, \\ e-mail: Iveta.Dembovska@rta.lv \\ ${ }^{3}$ Mg.soc.sc., researcher, Rezekne Academy of Technologies, Rezekne, Latvia, \\ e-mail: Inese.Silicka@rta.lv \\ ${ }^{4}$ Mg.chem., researcher, Rezekne Academy of Technologies, Rezekne, Latvia, \\ e-mail: Erika.Teirumnieka@rta.lv
}

\begin{abstract}
The consumption of functional food is increasing in almost all industrialized countries, not only because of an aging population but also because of a more enthusiastic lifestyle, which makes meeting the nutritional requirements more difficult. In part, the transition to processed, easily packaged and pre-cooked foods is considered to be a response to long working hours. It resulted in an increased demand for ready-to-eat foods in recent years and it is expected to continue growing. The aim of the research is to study and analyse the need for extruded field bean flour food products in the market. Methods used in the research - monographic, synthesis, statistical analysis methods. The research developed proposals for the sale of extruded field bean flour as a food raw material in different markets.
\end{abstract}

Keywords: extruded field beans, market analysis.

JEL code: 014, L66.

Received: 9 September 2021 Revised: 30 September 2021 Accepted: 17 November 2021

Published: 10 December 2021

\section{Introduction}

Current trends in the food industry incite scientists to study new food products and raw materials rich in proteins that would be adequate for consumers with intolerance or an allergy to specific food items. Scientists also study food products and raw materials obtained through the process of saving and renewing the resources of the Earth. One of such raw food material species is legumes: peas, beans, including field beans.

Field bean flour is characterized by a high content of fibre, microelements, proteins and some chemical substances, as well as the absence of gluten (wheat gluten). Unlike soybeans, field beans do not have such a high content of phytic acid, which prevents the absorption of minerals such as Zn, Ca, Mg in the body (Šterna et al., 2018). Apart from that, the latest studies have revealed negative influence of the consumption of soybeans on 
men's health. This all leads to the search for alternative sources of raw materials (Messiana, 2016).

Currently, one of the most limiting factors for producers in the use of alternative flours is the specific flavour of non-grain flour products. For producers of specific and functional foods, specific flavour may not be a limiting factor for the market, but for healthy consumer gluten-free flour products, flavour restriction is a significant barrier.

At present, there are no technologies available on the market that can remove the specific flavour of bean flour and ensure the taste properties of grain flour, while maintaining high nutritional value and gluten-free properties, as well as improving rheological and baking properties, thus ensuring the use of flour as a base raw material in food industries. This is evidenced by the fact that there is still no food on the store shelves made exclusively from field bean flour, without the addition of other flours, in order to ensure the structure and desired taste characteristics of the product.

The unique extrusion technology developed by RTA ensures the improvement of the rheological and baking properties of field bean flour, as well as the removal of the specific taste. The technology includes the use of various extrusion parameters (temperature, amount of added water, etc.), controlled heat supply to the foodstuff and the outer walls of the extruder, as well as defined parameters for the part of moisture content of raw materials during hot extrusion.

Use of the technology ensures the availability of basic raw material legume (field bean) flour which can be used in the production of food products, with the following advantages:

- the raw material has no specific taste of field beans and has the taste characteristics of grain flour;

- the raw material can be used for consumer healthy gluten-free flour products;

- the raw material does not have an adverse effect on health, including allergies, and has a higher content of fibre, trace elements, protein and certain chemicals than the most commonly used equivalent legume products on the market (soybeans).

The aim of the research is to study and analyse the need for extruded field bean flour food products in the market.

To achieve the research aim, the authors have set the following specific research tasks:

1) Study the sale of extruded field bean flour as a food raw material in the following markets:

- in the meat product market as an additive to meat mixtures;

- in the flour product market as a main ingredient or additive; 
- in the sweet and snack market, including chocolate, market as an additive;

- in the dairy product market as an additive.

2) Make conclusions and develop recommendations.

Research period: 2014-2020.

Hypothesis: The most promising application of the technology is to use it as the main raw ingredient or an additive in flour products.

Research novelty: The need for extruded field bean flour as a food raw material in different markets has been studied and analysed.

Research methods: monographic, synthesis, statistical analysis methods.

\section{Research results and discussion}

Currently a large proportion of biological resources produced in Latvia for the production of food products and animal feed, especially grains and milk, is exported as raw materials. These are products to which no value is added in Latvia. The ability of Latvia to produce biological resources is the main competitive advantage of its food industry (Zemkopības ministrija, 2018). Moreover, the increase in the demand for food and animal feed in other countries of the world can make Latvia's food production development even more attractive. This is why it is important to focus on the use of this potential in Latvia's food production industry. The development opportunities in the food industry which involve adding a higher value to raw materials produced in Latvia are the following:

1) production of quality products;

2) yield and production of functional food products;

3) design and production of innovative products.

The technology designed allows for more rational use of raw materials (field bean flour) by reducing raw material and food waste (Zemkopības ministrija, 2017).

The use of the technology results in raw material with a long shelf life (experimentally proven to be five years), which provides an advantage when creating supplies of food raw materials for the needs of the State in emergencies.

In the technology design process, parameters were obtained and tested, which allow using $100 \%$ bean flour, without adding wheat, corn, or other types of flour, thus excluding the possibility of the product containing gluten.

During the last few years, consumption of extruded snacks has rocketed in Europe, the United States, Japan and other countries and regions (Grand View Research, 2019). The local market also presents opportunities both for the existing participants of the market and the newcomers. As evaluated 
thoroughly in the technical and economic feasibility study (Rezekne Academy of Technologies, 2020), the target markets for the innovative technology of RTA are producers of meat, flour products, confectionery, and snacks, also including producers of chocolate, dairy products as well as public catering companies. Market trends are different for each of these segments.

\section{Meat industry market trends}

The global meat industry has experienced moderate market growth in the time period 2014 - 2020. Moderate growth is also forecasted for the time period until 2024. Market growth until 2020 was mainly driven by good economic growth in the region of Asia, India, and Indonesia. Developing markets are consuming more red meat, and consumers are increasingly seeing the connection between good health and a balanced diet (Marketline database, 2019).

The total revenue of the global meat market in 2018 was 924.75 billion US dollars, which represents a 3.3\% increase in the Compound Annual Growth Rate CAGR in the time period 2014 - 2018. In comparison, Asia, Pacific Ocean regions, and American markets grew by a CAGR of $2.8 \%$ and $1.8 \%$, respectively reaching revenue of 286.96 billion and 182.23 billion US dollars in 2018 (Marketline database, 2019).

The meat market is rapidly influencing consumer behaviour concerning vegetarian trends. According to global forecasts, approximately a third of global meat production will become a new type of meat product in the next 10 years, leading to a decrease of traditional meat products up to $40 \%$ (fig.1) (Gerhard et al., 2020).

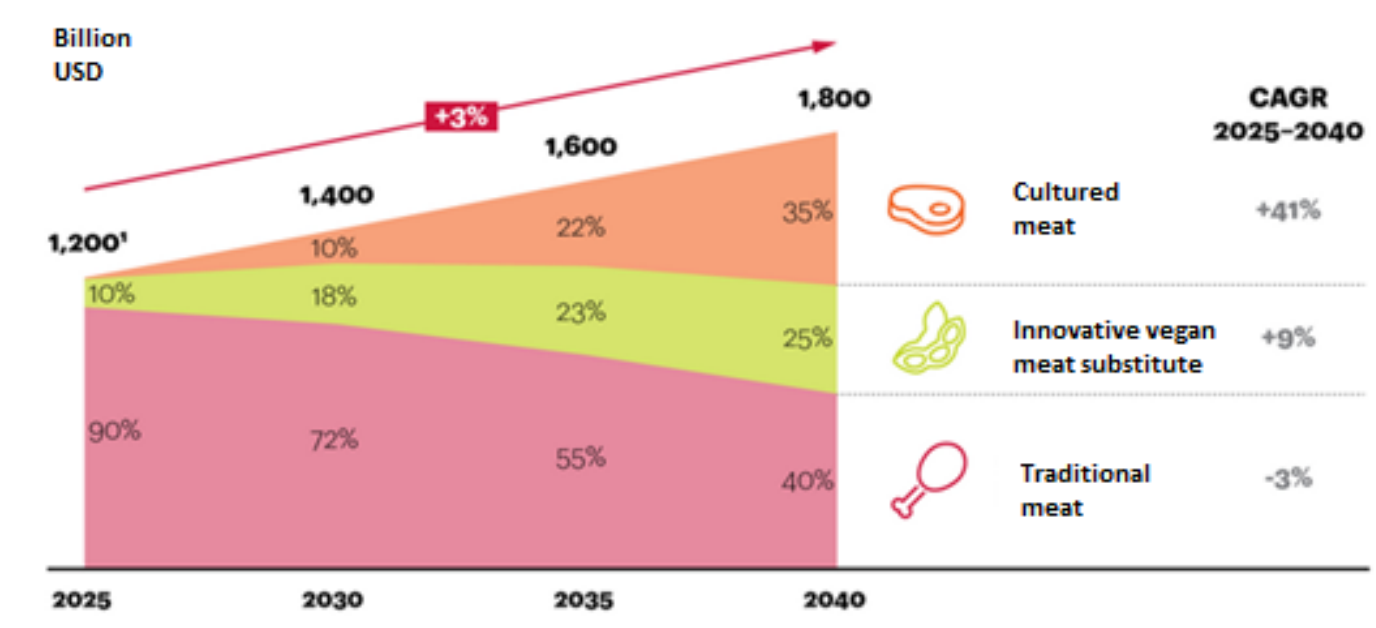

Fig.1 Global meat consumption forecast, CAGR 2025-2040

(Gerhardt et al., 2020) 
It is forecasted that the cultivated meat and the new meat substitutes are overall going to change the traditional 1,000 billion US dollars' worth meat industry with all its' suppliers. It is also going to be directly affected by the general shift to such proteins as legumes and nuts (replacing meat proteins), as well as regulatory measures against traditional meat. The successful development of the meat market in 2030 and beyond requires early investments, since supply chains, production and distribution channels need to be set up and adapted to the new market requirements (Gerhardt et al., 2020). The innovative technology of RTA directly applies to this new and rapidly growing demand.

In 2017, the Europe market was the largest market of meat substitutes, due to the growing consumer awareness about diet and meatless dishes, as well as the increasing prevalence of a flexitarian diet in this region. In addition, the growing number of meat counterfeits and spoiled meat cases has encouraged consumers to switch to a vegan diet, which presumably is going to promote the meat substitute market in this region (Markets and Markets, 2020).

The Europe meat market has experienced moderate growth in the time period of 2014 - 2018. It is forecasted that growth is going to stagnate in the coming years. Since the Europe meat market has stabilized, rapid growth is forecasted for certain segments, such as healthy and protein-rich meat snacks and meat products that are entirely or partly made of vegetarian ingredients, but which still retain the appearance and taste of the meat product (Allied Market Research, 2019a).

Chilled packaged whole meat cuts take up the largest volume of the European meat market in 2018, with total revenue of 90.51 billion US dollars, which makes up $27.9 \%$ of the total market value. In comparison, revenue from sales of fresh meat reached 77.79 billion US dollars in 2018, representing 24\% of the total market value (Allied Market Research, 2019a).

It is forecasted that the Europe meat market is going to grow by a 3.5\% CAGR between the years 2018 and 2023, boosting the market value to 385.66 billion US dollars by the end of 2023. In comparison, the German and UK markets will grow by $3.4 \%$ and $2.6 \%$, reaching 71.96 billion and 27.25 billion US dollars in 2023 (Allied Market Research, 2019a).

In 2017, the worth of this market was 4.1 billion US dollars. Furthermore, in 2017, Europe dominated the global meat substitute market, making 38.5\% of the total revenue (Allied Market Research, 2019a).

In developed markets, the increase of outlets for innovative, lowcholesterol meat products, such as lean meat, is limiting the growth of the meat substitute market. Generally, growing health concerns in developed countries have resulted in an increased number of consumers who prefer vegetarian food. Accordingly, it is forecasted that market operators will be 
provided with profitable opportunities to launch innovative meat substitutes in the coming years (Allied Market Research, 2019a).

Allied Market Research states that meat substitutes based on tofu and textured vegetable proteins dominate the global meat substitute market and are expected to maintain the dominant position throughout the forecast period (2019-2026).

Generally, meat consumption is increasing and trends suggest that this increase is going to continue. Demand in huge markets such as China and India are growing, due to population growth and prosperity. Fresh meat makes up almost $90 \%$ of the total meat consumption worldwide, with pork and poultry being the most popular. Consumption of poultry is high in several markets, while consumption of pork is mostly fixed in particular largest meat consuming regions - China - where it is most popular, and in Germany and France to a lesser extent (Allied Market Research, 2019b).

The future of meat consumption is divided into two groups: volume consumption in developing countries and the growth of meat hybrids in developed countries, as people in many developed countries are trying to reduce meat consumption. The market trend to reduce meat consumption to a large extent is motivated by consumers' concerns about their health, as well as concerns about the sustainability of the planet since the meat industry for many consumers is associated with a negative impact on the planet's ecosystem (FAIRR Briefing, 2018).

Worldwide, just over a fifth of consumers are trying to limit meat consumption, and Western Europe and the USA are the main markets where this trend is evident (CBINSIGTS, 2021). These markets then also outline the most promising markets for the innovative technology of RTA. In these markets, according to market trends, there is a growing demand for proteins and thus alternatives to the meat made from vegetarian materials.

\section{Flour product industry market trends}

As it was concluded in detail in the feasibility study, the flour products market tends to shift from the production of simpler flour-based food to more complex products, including extruded ones. Consumption of conventional flour-based food continues to decline in Western Europe and North America, in contrast to Asia, where sustainable growth is observed. Growth is also observed in the Middle East and Africa, as well as Latin America. In Western Europe, the share of consumers who actively reduce bread consumption is declining. However, in Western Europe the use of specifically processed bakery products is increasing (Euromonitor Passport, 2020).

Market trends show that the Middle East and Africa are the largest drivers of volume growth, while Europe is the largest market for functional 
flour products. With scientific progress that have contributed to the understanding of how nutrition affects human health, commercial opportunities have opened up for the development of a new food concept functional food. This is a relatively new approach focused on achieving the optimal health status, improving human well-being and reducing the risk of disease by choosing functional foods that help improve physical health. Consumers' interest in improving and maintaining their health by choosing functional foods has also promoted the development of the market by offering consumers a variety of functional foods including functional flour products (Bhat et al., 2011).

The Middle East and Africa have overtaken Western Europe to become the world's largest flour-based food market in terms of total volume (MarketWatch, 2021).

The addition of new ingredients or non-grain flour used for flour-based food production is a niche with a significant growth potential, mainly in Western Europe and North America. The aim of the new ingredients on the markets is to offer consumers healthier alternatives, especially with respect to fibres and proteins (Clare, 2002).

According to the TEC-made analysis, the baking of bulk bakery products has allowed retailers to strengthen their customer base and brands. Readyto-bake pastries produced on a commercial scale have been a fast-growing segment with a high profit margin, especially in markets where packaged baked goods have more sales than bulk. This has allowed retailers to strengthen their bargaining position and make a profit for flour producers. Demand for a variety of freshly baked supermarket products is expected to increase over the next five years, so the products alternative to bean meal could gain good growth prospects in this category as well (Allied Market Research, 2016).

Moreover, the market tendencies show that, despite the existence of a stagnant market for flour products in Europe, still it is the market that consumes the bulk of resources for flour-based food (per capita consumption), and this gives evidence to the existence of a potential demand for innovative, high-value products (Allied Market Research, 2016).

In summary, per capita GDP growth in Asia and global population growth worldwide remain the main drivers providing for the top-line growth of flour-based products. Lifestyle changes in developing countries will force consumers to replace home-made bread with the purchase of baked goods and, on the other hand, the search for new sources of floor will increase since the demand for alternative carbohydrate sources increases. As a result, more and more manufacturers are looking for novelties such as pea and bean protein (USA), insect powder, match tea, or other powders. 


\section{Market trends for confectionery and snacks, including the chocolate industry}

The global confectionery market has experienced moderate growth in the period from 2015 to 2019. Growth is expected to increase over the forecast period from 2019 to 2024, and the Covid-19 explosion will further increase growth in this market. There are several factors stimulating market growth. The total household income is increased, there is rapid urbanization all around, and a very dynamic lifestyle with little free time prevails; moreover, there is a growing tendency to donate confectionery products these are main factors promoting the worldwide growth of the confectionery market. However, more and more people become followers of a healthy lifestyle and opt for sugar-free confectionery. That is why manufacturers focus on healthier product innovations in combination with aggressive market strategies in order to increase sales volumes (Allied Market Research, 2020).

The global confectionery market was valued at $\$ 210.3$ billion in 2019 , and is projected to reach $\$ 270.5$ billion by 2027 , registering a CAGR of 3.6\%. In 2019, the chocolate segment accounted for the highest confectionery market share. Confections refer to food items that are rich in sugar and carbohydrates (Allied Market Research, 2020).

The confectionery market of Europe has experienced moderate growth within the period from 2015 to 2019. According to estimates, the growth will drop a little within the forecast period from 2019 to 2024 because of Covid19. Economic problems and the existing uncertainty as to about export and import regulations following Brexit will affect market growth, which worries European confectionery manufacturers. The confectionary market of Germany has the largest share of market consumption in 2019, which constitutes $15.6 \%$ of the total value of the European market; Great Britain is the second largest with $12.2 \%$. The demand for healthy and sugar-free confectionery is growing rapidly; they proved to be a substitute product in the market (Allied Market Research, 2020).

Covid-19 has also affected the European confectionery market, which is now expected to grow at a CAGR of 4.3\% to reach USD 91.081 million in 2024. Covid-19 also affected volume forecasts, the market is now projected to grow at a CAGR of $1.4 \%$, reaching the level of 6,453.2 million kilogram in 2024 (Marketline, 2020).

In Eastern Europe, as in Northern and Western Europe, the growth potential of sweets is associated with new, healthier alternatives, often involving combinations of innovative ingredients (Zhang et al., 2018). Extruded bean meal products are among these and it can therefore be concluded that market tendencies (Martinez-Monzo et al., 2013; Hassam et al., 2020; Malakar et al., 2020) are favourable. 


\section{Dairy products market trends}

The world market of dairy products experienced sustainable growth within the period from 2014 to 2018. The market growth is projected to increase within the period from 2018 to 2023. Such Asian countries as Indonesia, China and India have experienced rapid growth of the dairy market, which, in turn, contributed to the steady growth of the world dairy market as well. The main factors influencing the growth of the market are the increase of the population's income, rapid urbanization, and busy lifestyle. In turn, the popularity of a healthy lifestyle contributed to the production of healthy dairy products. Manufacturers are particularly focused on product packaging, including smaller and cheaper products (International Magazine..., 2021).

Market consumption increased by a CAGR of $1.4 \%$ between 2014 and 2018 , reaching $171,520.3$ million units in 2018. The market volume is expected to expand up to $183,271.6$ million units by the end of 2023, showing a 1.3\%-CAGR increase within the timeframe from 2018 to 2023 (International Magazine ..., 2021).

The confectionery market of Europe has experienced moderate growth within the period from 2015 to 2019. The market growth is projected to accelerate within the timeframe from 2018 to 2023 (International Magazine..., 2021).

Market trends indicate that market growth will accelerate to reach a 3\% CAGR increase between 2018 and 2023, which in turn will promote the increase in market value to USD 190,846.3 million by the end of 2023. In comparison, the German and British markets will grow at a CAGR constituting $2.6 \%$ and $3 \%$, respectively, reaching USD 32.963 .4 million and USD 20,071.2 million, respectively (International Magazine..., 2021).

It can be concluded that the market trends show the ever-widening range of functional dairy products entering the markets over the recent years. As already analysed in detail in the feasibility study, the origin of soy products has a poor reputation due to GMO presence therein, with the result that non-soy alternatives have grown rapidly. Peas and beans are one of the newest and fast-growing ingredients of the future - mainly due to their high protein content and sustainability.

\section{Public catering market trends}

The world catering industry has experienced modern growth before 2020; however, the industry was shocked by the Covid-19 pandemic, resulting in a substantial decrease. The industry is projected to recover by 2023 and see growth opportunities. Many of the leading chains that have been able to adapt to the new Covid-19 situation are now focusing on digital solutions and modifying the menu in terms of keeping health preservation 
principles rather than creating new vacancies. Covid-19 has changed the industry extremely significantly, and its future and market trends depend largely on the course of the pandemic. However, as most leading market analysts agree, the industry will have growth opportunities in the context of digitalisation and healthy eating (Chow,2020).

The global catering industry had total revenues of USD 3,246.8 billion in 2018, showing a 3.5\% increase in CAGR between 2014 and 2018. In comparison, industries in Asia-Pacific and the United States grew by $4.3 \%$ and $3.2 \%$ respectively, reaching USD 1,326.7 billion and USD 689.8 billion in 2018, respectively (Lock, 2021)

The public catering industry of Europe has also experienced moderate growth over the last years before 2020. In Europe, there was an increase in industrial transactions volume by a CAGR of $1.3 \%$ within the timeframe from 2014 to 2018, reaching 85.6 billion of transactions in 2018. In Europe, fast food restaurants are the most profitable segment of the industry in 2018, with the total revenues of USD $250.1-13824$, which is equivalent to $29.4 \%$ of the total value of the industry. Full-service restaurants accounted for 234.3 billion in 2018, which is equivalent to $27.6 \%$ of the total value of the industry (Marketline, 2019).

Despite the current economic situation, which is particularly difficult, the latest data for 2020 show that the catering industry is finding ways to grow and, despite the significant transformations, offering health diet and innovations will be compulsory to the industry in the years to come (Euromonitor, 2020).

\section{Conclusions and proposals}

Current trends in the food industry incite scientists to study new food products and raw materials rich in proteins that would be adequate for consumers with intolerance or an allergy to specific food items. Scientists also study food products and raw materials obtained through the process of saving and renewing the resources of the Earth. One of such raw food material species is legumes: peas, beans, including field beans.

During the last few years, consumption of extruded snacks has rocketed in Europe, the United States, Japan and other countries and regions. The local market also presents opportunities both for the existing participants of the market and the newcomers.

Worldwide, just over a fifth of consumers are trying to limit meat consumption, and Western Europe and the USA are the main markets where this trend is evident. These markets then also outline the most promising markets for the innovative technology of RTA. In these markets, according to 
market trends, there is a growing demand for proteins and thus alternatives to the meat made from vegetarian materials.

According to the TEC-made analysis, the baking of bulk bakery products has allowed retailers to strengthen their customer base and brands. Readyto-bake pastries produced on a commercial scale have been a fast-growing segment with a high profit margin, especially in markets where packaged baked goods have more sales than bulk. This has allowed retailers to strengthen their bargaining position and make a profit for flour producers. Demand for a variety of freshly baked supermarket products is expected to increase over the next five years, so the products alternative to bean meal could gain good growth prospects in this category as well.

In Eastern Europe, as in Northern and Western Europe, the growth potential of sweets is associated with new, healthier alternatives, often involving combinations of innovative ingredients. Extruded bean meal products are among these, and it can therefore be concluded that market tendencies are favourable.

It can be concluded that market trends show the ever-widening range of functional dairy products entering the markets over the recent years. As already analysed in detail in the feasibility study, the origin of soy products has a poor reputation due to genetically modified organism (GMO) presence therein, with the result that non-soy alternatives have grown rapidly. Peas and beans are one of the newest and fast-growing ingredients of the future mainly due to their high protein content and sustainability.

Despite the current economic situation, which is particularly difficult, the latest data for 2020 show that the catering industry is finding ways to grow and, despite the significant transformations, offering health diet and innovations will be compulsory to the industry in the years to come.

Within the framework of the national research programme "Covid-19 Mitigation", the issue of restructuring and strengthening the resilience of local food chains during the crisis and post-crisis in Latvia is being studied, where the potential food market in Latvia has been assessed. According to the CSB grain and legume balance data, in 2019, 226.1 thousand tons were processed into food for domestic consumption, and they were only $7 \%$ of the total amount of grain produced in Latvia this year (LLU, 2021).

The hypothesis has been proved.

\section{References}

1. Allied Market Research (2016). Flour Market by Raw Material (Wheat, Rice, Maize, and Others), Application (Bread \& Bakery Products; Noodles \& Pasta; Animal Feed; Wafers, Crackers, \& Biscuits; Non-Food Application; and Others), Technology (Dry Technology and Wet Technology) - Global Opportunity Analysis and Industry 
Forecast, 2014-2022. Retrieved from https://www.alliedmarketresearch.com/flourmarket

2. Allied Market Research. (2019a) Global Meat Substitute Market Expected to Reach $\$ 8.1$ Billion by 2026. Retrieved from https://www.alliedmarketresearch.com/pressrelease/global-meat-substitute-market.html

3. Allied Market Research. (2019b) Meat Substitute Market by Product, Source, Category: Global Opportunity Analysis and Industry Forecast, 2019-2026. Retrieved from https://www.alliedmarketresearch.com/meat-substitute-market

4. Allied Market Research. (2020). Confectionery Market by Product Type (Hard-Boiled Sweets, Mints, Gums \& Jellies, Chocolate, Caramels \& Toffees, Medicated Confectionery, Fine Bakery Wares, and Others), Age Group (Children, Adult, and Geriatric), Price Point (Economy, Mid-Range, and Luxury), and Distribution Channel (Supermarket/Hypermarket, Convenience Stores, Pharmaceutical \& Drug Stores, Food Services, Duty-Free Outlets, E-Commerce, and Others): Global Opportunity Analysis and Industry Forecast, 2021-2027. Retrieved from https://www.alliedmarketresearch.com/confectionery-market

5. Bhat, Z.F., Bhat, H. (2011) Functional Products: A Review. International Journal of Meat Science. Vol. 1-14, pp. 1.-14 Rerieved from https://docsdrive.com/pdfs/ansinet/ijmeat/2011/1-14.pdf

6. CBINSIGHTS (2021). Our Meatless Future: How the \$2,7T Global Meat Market Gets Disrupted. Retrieved from https://www.cbinsights.com/research/future-of-meatindustrial-farming/

7. Chow, L.S. (2020). Foodservice Waging War Against Covid-19 Crisis and the Opportunity. Journal of Tourism, Hospitality and Environment Management (JTHEM) Vol. 5 (19) (June 2020), 41-49. DOI 10/35631/JTHEM.519004

8. Clare, M. Hasler (2002). Functional Foods: Benefits, Concerns and Challenges-A Position Paper from the American Council on Science and Health, The Journal of Nutrition, 132(12), 3772-3781. Retrieved from https://academic.oup.com/in/article/132/12/3772/4712139

9. Euromonitor Passport (2020). Opportunities to Target the Ageing through Functional Food and Drink, 2020. Retrieved from https://www.euromonitor.com/opportunities-to-target-the-ageing-throughfunctional-food-and-drink/report

10. FAIRR Briefing. (2018). Plant-based profits: Investment risks \& opportunities in sustainable food systems, February 2018. Retrieved from https://www.longfinance.net/media/documents/FAIRR -

Sustainable Protein Report February 2018.pdf

11. Gerhardt, C., Suhlmann, G., ZiemBen, F., Donnan, D. (2020). How Will Cultured Meat and Meat Alternatives Disrupt the Agricultural and Food Industry? Industrial Biotechnology, 16(5), https://doi.org/10.1089/ind.2020.29227.cge

12. Grand View Research (2019). Snacks Market Size, Share \& Trends Analysis Report By Type (Extruded (Potato, Corn, Rice), Non-extruded (Salty, Refrigerated, Bakery)), By Distribution Channel (Supermarkets \& Hypermarkets, Online), And Segment Forecasts, 2019 - 2025. Retrieved from https://www.grandviewresearch.com/industryanalysis/snacks-market

13. Hassan,H., Bakar Sade,A., Subramaniam, L.S. (2020). Purchasing functional foods to stay fit. Journal of Humanities and Applied Social Sciences, 2(1), 3-18. Retrieved from https://www.emerald.com/insight/content/doi/10.1108/IHASS-11-2019$\underline{0073 / \mathrm{full} / \mathrm{pdf}}$ 
14. International Magazine for Animal Feed \& Additives Industry (2021). Global Dairy Industry and Trends. Retrieved from https://www.feedandadditive.com/globaldairy-industry-and-trends/

15. Lock, S. (2021). U.S. caterers industry market size 2011-2021. Retrieved from https://www.statista.com/statistics/1174156/caterer-industry-market-size-us/

16. LLU (2021). Valsts pētījumu programmas „Civid-19 seku mazināšanai” projekts „Ekonomiskais, politikskais un juridiskais ietvars Latvijas tautsaimniecības potenciāla saglabāšanai un konkurētspējas pieauguma veicināšanai pē pandēmijas izraisītās krīzes (reCOVery-LV)” apakšprojekts „Vietējo pārtikas kēěžu pārstrukturizēšana un noturības stiprināšana krīzes un pēckrīzes laukā Latvijä"ziṇojums I daḷa. Retrieved from:

https://www.llu.lv/sites/default/files/files/projects/zinojums partikas\%20kedes VPP reCOVery 01 2021.pdf

17. Malakar,S., Paul,S.K., Jolvis Pou K.R. (2020). Biotechnological Interventions in Beverage Production. Biotechnological Progress and Beverage Consumption, 19, The Science of Beverages, 1-37. https://doi.org/10.1016/B978-0-12-816678-9.00001-1

18. Marketline (2020) Foodservice Global Industry Guide 2014-2023. Retrieved from https://store.marketline.com/report/mlig190034-06--foodservice-global-industryguide-2014-2023/

19. Marketline (2020). Global Confectionery. Retrieved from https://store.marketline.com/report/ohmf10435--global-confectionery-6/

20. Marketline database (2019). Total global meat market value growth CAGR 2014.-2018. Retrieved from https://store.marketline.com/report/ohme9924--global-meat/

21. MarketsandMarkets. (2020). Meat Substitutes Market by Source (Soy protein, Wheat protein, Pea protein), Type (Concentrates, Isolates, and Textured), Product (Tofu, Tempeh, Seitan, and Quorn), Form (Solid and Liquid), and Region - Global Forecast to 2026. Retrieved from https://www.marketsandmarkets.com/Market-Reports/meatsubstitutes-market-

979.html?gclid=EAIaIQobChMIqKLytOKt5QIVkumaCh3PiA2gEAAYASAAEgJRqPD B wE

22. MarketWatch (2021). Bakery Market 2021 Share, Size Global Production, Business Growth, Industry Revenue, Demand and Applications Market Research Report to 2027. Retrieved from https://www.marketwatch.com/press-release/bakery-market2021-share-size-global-production-business-growth-industry-revenue-demandand-applications-market-research-report-to-2027-2021-06-14

23. Martínez-Monzó, J., Garcia-Segovia,P., Albors-Garrigos, J. (2013). Trends and Innovations in Bread, Bakery, and Pastry. Journal of Culinary Science \& Technology, 11(1): Creativity and Innovation in Haute Cuisine, 56-65. https://doi.org/10.1080/15428052.2012.728980

24. Messiana, M. (2016). Soy and Health Update: Evaluation of the Clinical and Epidemiologic Literature. Nutrients, 8(12), 754. DOI 10.3390/nu8120754

25. Rezekne Academy of Technologies (2020). Innovative Technologies-Technology for Manufacturing of Food products from Extruded Field Bean Flour and Applications of the Products.

26. Šterna, V., Zute, S., Jansone, I., Zariṇa, L., Bleidere,M. (2018). Dažādu pākšaugu audzēšanas potenciāls vietējā proteīna ražošanai. IV Pasaules latviešu zinātnieku kongress, Lauksaimniecības un meža zinātṇu sekcija. 
27. Zemkopības ministrija (2017). Informatīvais zin,ojums. Latvijas Bioekonomikas stratēgija 2030. Retrieved from: https://www.llu.lv/sites/default/files/201807/Bioeconomy Strategy Latvia LV.pdf

28. Zemkopības ministrija (2018). Latvijas lauksaimniecība. Retrieved from: https://www.zm.gov.lv/public/files/CMS Static Page Doc/00/00/01/33/19/Gadaz inojums.pdf

29. Zhang, L., Boom, R.M., Chen, X.D., Schutyser,M.A.I. (2018). Recent Developments in Functional Bakery Products and the Impact of Baking on Active Ingredients. IDS'2018 21st International Drying Symposium València, Spain, 11-14 September 2018. Retrieved from http://dx.doi.org/10.4995/ids2018.2018.7593 